\author{
Zh.N. Tasmambetov ${ }^{1}$, Zh.K. Ubayeva ${ }^{2}$ \\ ${ }^{1}$ Aqtobe Regional Zhubanov State University, Kazakhstan; \\ ${ }^{2}$ K. Zhybanov Aktobe regional state university, Kazakhstan \\ (E-mail: tasmam@rambler.ru,Zhanar_ubaeva@mail.ru)
}

\title{
Solution of inhomogeneous systems for differential equations in private derivatives of the third order
}

\begin{abstract}
The possibilities of constructing inhomogeneous system solutions for partial differential equations of the third order have been studied. The construction of general and particular solutions corresponding to homogeneous system comprehensively investigated by using Frobenius-Latysheva method. Type of solutions near the special curves are established. The number of linearly independent partial solutions is determined. A theorem on the representation a general solution of inhomogeneous system is proved, and the application of uncertain coefficients method for such systems is revealed. On a concrete example, it is shown that the particular solutions of the inhomogeneous system constructed in this way are solutions of one inhomogeneous third-order equation obtained by adding the two equations of the considered example. One of particular solutions corresponding to homogeneous system relates to degenerate generalized hypergeometric series of Clausen type with two variables. Properties of generalized hypergeometric series are still poorly understood.
\end{abstract}

Keywords: inhomogeneous system, regular solution, singularity, method of undetermined coefficients, system, equations, theorem.

\section{Introduction}

Systems consisting of two partial differential equations of the second and third orders with a common unknown have long attracted the attention of mathematicians. The American mathematician E.J. Wilczynski used the system of second order to substantiate projective differential geometry [1]. Further research of such systems is associated with the study of generalized hypergeometric functions of two variables, in particular the four Appell hypergeometric functions $F_{1}-F_{4}$ [2; 155-169], [3; 210-231].

J. Horn studied the convergence of all 34 hypergeometric series in two variables and established systems of partial differential equations of second order which they satisfy [4; 218-233].

In a number of works Zh.N. Tasmambetov $[5,6]$ proved that almost all Horn's systems are special cases of a regular joint system of second-order partial differential equations that consist of two equations

$$
\begin{aligned}
& x^{2} g^{(0)} Z_{x x}+x y g^{(1)} Z_{x y}+y^{2} g^{(2)} Z_{y y}+x g^{(3)} Z_{x}+y g^{(4)} Z_{y}+g^{(5)} Z=0, \\
& y^{2} q^{(0)} Z_{y y}+x y q^{(1)} Z_{x y}+x^{2} q^{(2)} Z_{x x}+x q^{(3)} Z_{x}+y q^{(4)} Z_{y}+q^{(5)} Z=0,
\end{aligned}
$$

with coefficients in the form of polynomials

$$
\begin{gathered}
g^{(i)}(x, y)=a_{00}^{(i)}+a_{10}^{(i)} x^{k}, \\
q^{(i)}(x, y)=b_{00}^{(i)}+b_{01}^{(i)} y^{k} \cdot(i=\overline{0,5} ; k-\text { integer }) .
\end{gathered}
$$

The classification of their singular curves, the construction of solutions near singular curves and the existence of logarithmic solutions, etc. were considered.

For different values of $\mathrm{k}$ from (1.1) we get a number of interesting systems.

1. When $k=0$ from (1.1) we obtain a system of Euler type [6; 242-249].

2 . When $k=1, a_{10}^{(5)}=0, b_{01}^{(5)}=0$, then we obtain a hypergeometric type system, since the solutions of such systems are the hypergeometric functions of two variables [5; 316-319]. 
3. Transformation

$$
x^{k}=u, y^{k}=v
$$

leads the system to the previous view.

4. When $k \geq 2$ from system (1.1) as a special case, the systems are obtained whose solutions are the orthogonal polynomials of two variables. They are expressed through the functions of Appell. Specific examples of the application are shown in the works [2; 155-169], [7; 655-661].

5. The general condition for the compatibility of such systems is established [1]. In addition, the integrability condition must be satisfied

$$
1-\frac{g^{(1)}}{g^{(0)}} \cdot \frac{q^{(1)}}{q^{(0)}} \neq 0
$$

6. Under these important conditions, system (1.1) has four linearly independent particular solutions [1]. The overall solution is represented as the sum of these four solutions

$$
Z(x, y)=\sum_{i=1}^{4} C_{i} Z_{i}(x, y) .
$$

If condition (1.4) is not satisfied, then the system has at most three linearly independent particular solutions. Until now, inhomogeneous systems of the form

$$
\begin{aligned}
& P^{(0)} Z_{x x}+P^{(1)} Z_{x y}+P^{(2)} Z_{x}+P^{(3)} Z_{y}+P^{(4)} Z=P^{(5)}(x, y), \\
& Q^{(0)} Z_{y y}+Q^{(1)} Z_{x y}+Q^{(2)} Z_{x}+Q^{(3)} Z_{y}+Q^{(4)} Z=Q^{(5)}(x, y),
\end{aligned}
$$

still insufficiently investigated, where $P^{(i)}=P^{(i)}(x, y), Q^{(i)}=Q^{(i)}(x, y)$ analytic functions of two variables. Although the works of Zh.N. Tasmambetov and M.Zh. Talipova $[8,9]$ are studied the possibilities of constructing solutions for inhomogeneous systems of the form (1.5) and some special cases of it. As in the ordinary case [10; 146], the rightness of assertion is proved [8].

Theorem 1.1. The general solution of the inhomogeneous system (1.5) is represented as the sum of the total solution (1.4):

$$
\bar{Z}=\sum_{j=1}^{4} C_{j} Z_{j}(x, y),(j=1,2,3,4)
$$

corresponding homogeneous system and particular solution $Z_{0}(x, y)$ of inhomogeneous system (1.5):

$$
Z(x, y)=\bar{Z}(x, y)+Z_{0}(x, y)=\sum_{j=1}^{4} C_{j} Z_{j}(x, y)+Z_{0}(x, y)
$$

Disseminate previous results obtained from second-order system case to the case with system consisting of two third-order equations. Determine the number of solutions corresponding to homogeneous system, near singular curves. Carry out classification of singular curves and establish the type of inhomogeneous system solutions. Develop specific examples.

\section{Main results}

2. Construction of homogeneous system solutions consisting two equations of third order

Problem statement. A nonhomogeneous regular system consisting two third-order partial differential equations near the singularity is considered.

$$
x^{3} g^{(0)} Z_{x x x}+x^{2} y g^{(1)} Z_{x x y}+x^{2} g^{(2)} Z_{x x}+x y g^{(3)} Z_{x y}+x g^{(4)} Z_{x}+y g^{(5)} Z_{y}+g^{(6)} Z=g^{7}(x, y),
$$




$$
y^{3} q^{(0)} Z_{y y y}+x y^{2} q^{(1)} Z_{x y y}+y^{2} q^{(2)} Z_{y y}+x y q^{(3)} Z_{x y}+x q^{(4)} Z_{x}+y q^{(5)} Z_{y}+q^{(6)} Z=q^{7}(x, y),
$$

where $Z=Z(x, y)$ total unknown, coefficient

$$
\begin{gathered}
g^{(i)}=g^{(i)}(x, y)=a_{00}^{(i)}+a_{10}^{(i)} x^{k} \\
q^{(i)}=q^{(i)}(x, y)=b_{00}^{(i)}+b_{01}^{(i)} y^{k},(i=\overline{0,6})
\end{gathered}
$$

and the right parts $g^{(7)}(x, y), q^{(7)}(x, y)$ analytic functions or polynomials of two variables. Required to construct a general solution of inhomogeneous system (2.1) with coefficients in type (2.2) and show that it is represented as the sum of total solution $Z_{0}(x, y)$ corresponding to homogeneous system and particular solution of inhomogeneous system (2.1).

2.1. Construction of regular solutions corresponding to homogeneous system

Construction features of regular solutions corresponding to homogeneous system

$$
\begin{aligned}
& x^{3} g^{(0)} Z_{x x x}+x^{2} y g^{(1)} Z_{x x y}+x^{2} g^{(2)} Z_{x x}+x y g^{(3)} Z_{x y}+x g^{(4)} Z_{x}+y g^{(5)} Z_{y}+g^{(6)} Z=0, \\
& y^{3} q^{(0)} Z_{y y y}+x y^{2} q^{(1)} Z_{x y y}+y^{2} q^{(2)} Z_{y y}+x y q^{(3)} Z_{x y}+x q^{(4)} Z_{x}+y q^{(5)} Z_{y}+q^{(6)} Z=0,
\end{aligned}
$$

where $Z=Z(x, y)$ total unknown, not studied enough.

This system requires the establishment of a general method for constructing solutions near regular singularities $(0,0)$ and $(\infty, \infty)$, determining the number of linearly independent solutions, as well as the classification of regular and irregular singularities, compatibility conditions and integrality. Systems (1.1) and (2.3) differ only in orders. Therefore, to construct a third-order system solution (2.3), it is advisable to use the Frobenius-Latysheva method [6], which has proved itself well in studying the second-order system (1.1).

The use of this method involves the fulfillment a number of conditions:

1. Suppose that system (2.3) is joint and the integrality condition is also represented in type (1.3). However, these concepts need further clarification.

2. Special curves at $k=1$ determine by equating the coefficients at higher derivatives to zero $Z_{x x x}$ and $Z_{y y y}:(0,0),\left(0,-b_{00}^{(0)} / b_{01}^{(0)}\right),\left(-a_{00}^{(0)} / a_{01}^{(0)}, 0\right),\left(-a_{00}^{(0)} / a_{01}^{(0)}\right),\left(-b_{00}^{(0)} / b_{01}^{(0)}\right),(0, \infty),(\infty, 0),\left(\infty,-b_{00}^{(0)} / b_{01}^{(0)}\right)$, $\left(-a_{00}^{(0)} / a_{01}^{(0)}, \infty\right)$. As before, single out two pairs of features $(0,0)$ and $(\infty, \infty)$ at building a solution.

3 . In case under consideration, the coefficient (2.2) is reduced to the form of the previous case, using the transformation (1.2).

4. The solution near the feature $(0,0)$ is represented as

$$
Z(x, y)=x^{\rho} y^{\sigma} \sum_{m, n=0}^{\infty} A_{m, n} x^{m} y^{n}, A_{0,0} \neq 0
$$

a near the feature $(\infty, \infty)$ in form

$$
Z(x, y)=x^{\rho} y^{\sigma} \sum_{m, n=0}^{\infty} B_{m, n} x^{-m} y^{-n}, B_{0,0} \neq 0
$$

where $\rho, \sigma, A_{m, n}, B_{m, n}(m, n=0,1,2,3, \ldots)$ unknown constants.

The application of the Frobenius-Latysheva method assumes [6] compilation characteristic functions system and determination systems of defining equations for the singularity $(0,0)$ :

$$
\begin{gathered}
f_{00}^{(1)}(\rho, \sigma)=a_{00}^{(0)} \rho(\rho-1)(\rho-2)+a_{00}^{(1)} \rho(\rho-1) \sigma+a_{00}^{(2)} \rho(\rho-1)+a_{00}^{(3)} \rho \sigma+a_{00}^{(4)} \rho+a_{00}^{(5)} \sigma+a_{00}^{(6)}=0, \\
f_{00}^{(2)}(\rho, \sigma)=b_{00}^{(0)} \sigma(\sigma-1)(\sigma-2)+b_{00}^{(1)} \sigma(\sigma-1) \rho+b_{00}^{(2)} \sigma(\sigma-1)+b_{00}^{(3)} \rho \sigma+b_{00}^{(4)} \rho+b_{00}^{(5)} \sigma+b_{00}^{(6)}=0,
\end{gathered}
$$


and concerning feature $(\infty, \infty)$ :

$$
\begin{gathered}
f_{10}^{(1)}(\rho, \sigma)=a_{10}^{(0)} \rho(\rho-1)(\rho-2)+a_{10}^{(1)} \rho(\rho-1) \sigma+a_{10}^{(2)} \rho(\rho-1)+a_{10}^{(3)} \rho \sigma+a_{10}^{(4)} \rho+a_{10}^{(5)} \sigma+a_{10}^{(6)}=0, \\
f_{01}^{(2)}(\rho, \sigma)=b_{01}^{(0)} \sigma(\sigma-1)(\sigma-2)+b_{01}^{(1)} \sigma(\sigma-1) \rho+b_{01}^{(2)} \sigma(\sigma-1)+b_{01}^{(3)} \rho \sigma+b_{01}^{(4)} \rho+b_{01}^{(5)} \sigma+b_{01}^{(6)}=0 .
\end{gathered}
$$

From (2.6) have been determined indicators of the series (2.4), and from (2.7) row indicators (2.5) as pairs $\left(\rho_{t}, \sigma_{t}\right)$. It is important to determine the index $t$, since the number of such pairs allows determining the number of linearly independent particular solutions of system $(2.3)$ near the singularities $(0,0)$ and $(\infty, \infty)$

Theorem 2.1. If the system (2.3) with coefficient type (2.2), where coefficient $a_{00}^{(0)} \neq 0$, $b_{00}^{(0)} \neq \neq \neq, h=1$ meet compatibility conditions. Then the system $(2.3)$ near the singularity $(0,0)$ has nine linearly independent regular particular solutions in type $(2.4)$, where row indicators $\left(\rho_{t}, \sigma_{t}\right)$, $(t=\overline{1,9})$ are determined from the system of defining equations (2.6), and unknown coefficients $A_{m, n}^{(t)}(m, n=0,1, \ldots ; t=\overline{1,9})$ series $(2.4)$ determined from recurrent sequence systems

$$
\sum_{m, n=0}^{\infty} A_{\mu-m, \nu-n}^{(t)} f_{m, n}^{(j)}(\rho+\mu-m, \sigma+\nu-n)=0
$$

$(\mu, \nu=0,1,2, \ldots, ; j=1,2 ; t=\overline{1,9})$ obtained by substituting a series (2.4) to the original system (2.3) with coefficients of the form (2.2).

Proof. In general, to establish compatibility conditions is very difficult. If the system is hypergeometric type, then compatibility conditions are determined by the Kampe de Feriet method [2; 155-159]. The method for hypergeometric type of equations is shown in [11; 21]. Determine how many roots have the system of defining equations (2.6) and (2.7). To this end, write down system (2.6) in expanded form, using (2.5). From the second equation $f_{00}^{(2)}(\rho, \sigma)=0$ we have discovered

$$
\rho=\frac{b_{00}^{(0)} \sigma(\sigma-1)(\sigma-2)+b_{00}^{(2)} \sigma(\sigma-1)+b_{00}^{(5)} \sigma+b_{00}^{(6)}}{b_{00}^{(1)} \sigma(\sigma-1)+b_{00}^{(3)} \sigma+b_{00}^{(4)}}
$$

and substituting in the first equation $f_{00}^{(1)}(\rho, \sigma)=0$ systems (2.6), after exclusion $\sigma$ get the ninth degree equation for $\rho$. In the case when only simple roots exist, it is possible to determine the nine roots of the resulting equation. In the same way, we define nine simple roots $\sigma_{t},(t=\overline{1,9}$ and make of them nine pairs of roots $\left(\rho_{t}, \sigma_{t}\right),(t=\overline{1,9})$. These indicators correspond to nine linearly-independent particular solutions of the system (2.1) and (2.2), after determining unknown coefficient $A_{m, n}^{(t)},(m, n=0,1,2, \ldots ; t=\overline{1,9})$ from the system of recurrent sequences (2.8). Similarly, we can verify that system (2.1) and (2.2) also has nine linearly independent particular solutions near the singularity $(\infty, \infty)$.

Theorem 2.2. If systems (2.1) and (2.2), where coefficient $a_{10}^{(0)} \neq 0, b_{01}^{(0)} \neq 0, h=1$ conditions of compatibility and integrability are satisfied (1.3). When systems $(2.1)$ near the singularities $(\infty, \infty)$ have nine linearly independent regular partial solutions in type (2.5), where a number of indicators $\rho_{t}, \sigma_{t}(t=\overline{1,9})$ determined from the system of defining equations (2.7), and unknown coefficients $B_{m, n}^{(t)}(m, n=0,1,2, \ldots ; t=\overline{1,9})$ series $(2.4)$ determined from recurrent sequence systems

$$
\sum_{m, n=0}^{\mu, \nu} B_{\mu-m, \nu-n}^{(t)} f_{m, n}^{(j)}(\rho-\mu+m, \sigma-\nu+n)=0,
$$

$(\mu, \nu=0,1,2, \ldots, ; j=1,2 ; \mu-m \geq 0, \nu-n \geq 0, t=\overline{1,9})$ obtained by substituting series (2.4) into the original system $(2.1),(2.2)$. 
In Theorems 2.1 and 2.2, the conditions $a_{00}^{(0)} \neq 0, b_{00}^{(0)} \neq 0$ and $a_{10}^{(0)} \neq 0, b_{01}^{(0)} \neq 0$ essential since the ninth degree equations are relatively $\rho$ and $\sigma$ turns out only when they are non-zero. This shows that near regular singular curves $(0,0)$ and $(\infty, \infty)$ there are nine regular linearly independent particular solutions $Z_{t}(x, y),(t=\overline{1,9})$.

Theorem 2.3. Common solution of joint system (2.1), (2.2) in case of the integrability condition (1.3) is satisfied, is represented as the sum

$$
\bar{Z}(x, y)=\sum_{i=1}^{9} C_{i} Z_{i}(x, y),(t=\overline{1,9})
$$

where $C_{i}(t=\overline{1,9})$ arbitrary constant.

Remark 2.1. Theorems 2.1 and 2.2 have been formulated for the case $h=1$. This is due to the classification of singular curves. They are true and generally, where $k \geq 2$. Then particular solutions are expressed through $Z=Z\left(x^{k}, y^{k}\right),(k \geq 2)$.

Remark 2.2. Theorem 2.3 is also valid when the coefficients of system (2.1) are analytic functions or polynomials of two variables.

2.2. Construction of inhomogeneous system solutions.

A theorem on the construction a general solution is formulated analogously to Theorem 1.1.

Theorem 2.4. The general solution of inhomogeneous system (2.1) is represented as the sum of total solution $Z(x, y)$ corresponding to homogeneous system (2.3) and a particular solution $Z_{0}(x, y)$ of inhomogeneous system (2.1):

$$
Z(x, y)=\bar{Z}(x, y)+Z_{0}(x, y)=\sum_{t=1}^{9} C_{t} Z_{t}(x, y)+Z_{0}(x, y)
$$

The form of the general solution (2.9) is established by Theorem 2.3. To construct a particular solution near the singularity $(0,0)$, we apply the method of undetermined coefficients generalized for the case of two variables series. To this end, a series of the form (2.4) representing a particular solution $Z(x, y)$ substitute into the inhomogeneous system (2.1) and obtain the system of Frobenius characteristic functions

$$
\begin{aligned}
& x^{\rho} y^{\sigma}\left\{C_{0,0} f_{0,0}^{(j)}(\rho, \sigma)+\left[C_{1,0} f_{0,0}^{(j)}(\rho+1, \sigma)+C_{0,0} f_{1,0}^{(j)}(\rho, \sigma)\right] x+\left[C_{0,1} f_{0,0}^{(j)}(\rho, \sigma+1)+C_{0,0} f_{0,1}^{(j)}(\rho, \sigma)\right] y+\right. \\
& \left.+\left[C_{1,1} f_{0,0}^{(j)}(\rho+1, \sigma+1)+C_{1,0} f_{0,1}^{(j)}(\rho+1, \sigma)+C_{0,1} f_{1,0}^{(j)}(\rho, \sigma+1)+C_{0,0} f_{1,1}^{(j)}(\rho, \sigma)\right] x y+\ldots\right\} \equiv f_{j}(x, y)
\end{aligned}
$$

where $f_{1}(x, y)=g^{7}(x, y), f_{2}(x, y)=q^{7}(x, y)$ and $f_{0,0}^{(j)}(\rho, \sigma),(j=1,2)$ determines the system of defining equations for the singularity $(0,0)$ of the form $(2.6)$.

Further reasoning depends on form of right side representation $f_{j}(x, y),(j=1,2)$. Let them be represented as generalized power series of two variables in increasing degrees of independent variables $x$ and $y$ :

$$
\begin{aligned}
& f_{1}(x, y)=g^{(7)}(x, y)=x^{\alpha} y^{\beta} \sum_{m, n=0}^{\infty} a_{m, n} x^{m} y^{n},\left(a_{0,0} \neq 0\right) \\
& f_{2}(x, y)=q^{(7)}(x, y)=x^{\gamma} y^{\delta} \sum_{m, n=0}^{\infty} b_{m, n} x^{m} y^{n},\left(b_{0,0} \neq 0\right)
\end{aligned}
$$

Then a series of form (2.4) representing a particular solution

$$
Z_{0}(x, y)=x^{\rho} y^{\sigma} \sum_{m, n=0}^{\infty} C_{m, n} x^{m} y^{n},\left(C_{0,0} \neq 0\right)
$$


will be a formal particular solution only when uncertain coefficients $C_{m, n}(m, n=0,1,2, \ldots)$ satisfy the following recurrent system

$$
\begin{gathered}
C_{0,0} f_{00}^{(j)}(\rho, \sigma)=\alpha_{0,0}^{(j)} \\
C_{1,0} f_{00}^{(j)}(\rho+1, \sigma)+C_{0,0} f_{10}^{(j)}(\rho, \sigma)=\alpha_{1,0}^{(j)} \\
C_{0,1} f_{00}^{(j)}(\rho, \sigma+1)+C_{0,0} f_{01}^{(j)}(\rho, \sigma)=\alpha_{0,1}^{(j)} \\
C_{1,1} f_{00}^{(j)}(\rho+1, \sigma+1)+C_{1,0} f_{01}^{(j)}(\rho+1, \sigma)+C_{0,1} f_{10}^{(j)}(\rho, \sigma+1)+C_{0,0} f_{11}^{(j)}(\rho, \sigma)=\alpha_{1,1}^{(j)} \\
C_{2,0} f_{00}^{(j)}(\rho+2, \sigma)+C_{1,0} f_{10}^{(j)}(\rho+1, \sigma)+C_{0,0} f_{20}^{(j)}(\rho, \sigma)=\alpha_{2,0}^{(j)} \\
C_{0,2} f_{00}^{(j)}(\rho, \sigma+2)+C_{0,1} f_{01}^{(j)}(\rho, \sigma+1)+C_{0,0} f_{02}^{(j)}(\rho, \sigma)=\alpha_{0,2}^{(j)}
\end{gathered}
$$

The recurrent system determines the coefficients $C_{m, n}(m, n=0,1,2, \ldots)$ of series $(2.12)$. When $j=1$ and $j=2$ it breaks down into two systems. When $j=1$ in the right part $(2.13) \alpha_{m, n}^{(1)}=a_{m, n}$ at $j=2$ coefficients $\alpha_{m, n}^{(2)}$ determines over $b_{m, n}(m, n=0,1, \ldots)$, where $a_{m, n}$ and $b_{m, n}$ coefficients of generalized power series $g^{(7)}(x, y)$ and $q^{(7)}(x, y)$. Coefficient $C_{m, n}(m, n=0,1,2, \ldots)$ determined at $j=1$ and $j=2$ of the two sequences of recurrent systems must be identical. From the recurrent system (2.13) they are determined only under the condition $\left(\alpha+k_{1}, \beta+k_{1}\right)$ and $\left(\gamma+k_{2}, \delta+k_{2}\right)$ where $k_{j}(j=1,2)$ any natural numbers, are not indicators of homogeneous system (2.3) solution. Series convergence $f_{j}(x, y)(j=1,2)$ involves the convergence of right-hand side series (2.12). When fulfilling the above conditions, particular solution $Z_{0}(x, y)$ the inhomogeneous system (2.1) with coefficients of the form $(2.2)$, when the singularity $(0,0)$ can be constructed regularly.

Remark 2.3. If $\left(\alpha+k_{1}, \beta+k_{1}\right)$ and $\left(\gamma+k_{2}, \delta+k_{2}\right)$, where $k_{j}(j=1,2)$ any positive integers are indices of homogeneous system solution, then we obtain a more complicated «resonance»case. This case requires additional investigation.

Remark 2.4. If in coefficients (2.2) constant $k=1$, then in the recurrent sequence starting from $f_{1,1}^{(j)}(\rho, \sigma)$ all expressions $f_{2,0}^{(j)}(\rho, \sigma), f_{0,2}^{(j)}(\rho, \sigma), f_{3,0}^{(j)}(\rho, \sigma), \ldots$ will be zero.

Remark 2.5. The transformation (1.2) of the considered case will lead to a simpler form $k=1$.

Thus, based on the above reasoning, we can conclude that the statement is true.

Lemma 2.1. Let inhomogeneous system consisting of two third-order equations (2.1) with coefficients in type (2.2), where the right-hand sides $g^{(7)}(x, y)$ and $q^{(7)}(x, y)$ analytic functions of two variables regular near the singularity $(x=0, y=0)$. Then system's particular solution (2.1) has the form of the right-hand side (2.11), if $\left(\alpha+k_{1}, \beta+k_{1}\right)$ and $\left(\gamma+k_{2}, \delta+k_{2}\right)$ does not coincide with any pair of solution indicators corresponding to the homogeneous system (2.3) for any natural $k_{j}(j=1,2)$.

2.3. Construction and study properties of specific system solutions

J. Kampe de Feriet [2; 155-162] provides a method for constructing systems of third and fourth orders consisting of two equations, using the system

$$
\begin{aligned}
& \sum_{j+k=0}^{j+k=\omega+1}\left(\rho_{j, k}-\alpha_{j, k} x\right) x^{j} y^{k} p_{j, k}=0 \\
& \sum_{j+k=0}^{j+k=\omega+1}\left(\sigma_{j, k}-\beta_{j, k} y\right) x^{j} y^{k} p_{j, k}=0 .
\end{aligned}
$$

This technique ensures the compatibility of two equations systems hypergeometric type (2.3). The solutions of such systems are generalized by hypergeometric functions of two variables. Consider a particular special case $[2 ; 159]$ of such system and we will study the properties of its solutions. 
Theorem 2.5. The system of partial differential equations consisting two equations of third order

$$
\begin{gathered}
x^{2} Z_{x x x}+x y Z_{x x y}+(\gamma+\delta+1) x Z_{x x}+\delta y Z_{x y}+\gamma \delta Z_{x}-Z=0, \\
y^{2} Z_{y y y}+x y Z_{x y y}+\left(\gamma+\delta^{\prime}+1\right) y Z_{y y}+\delta^{\prime} x Z_{x y}+\gamma \delta^{\prime} Z_{y}-Z=0,
\end{gathered}
$$

has nine linearly independent particular solutions

$$
\begin{gathered}
Z_{1}(x, y)=F\left(\cdot ; \delta, \delta^{\prime}, \gamma ; x, y\right)=\sum_{m, n=0}^{\infty} \frac{1}{(\delta)_{m}\left(\delta^{\prime}\right)_{n}(\gamma)_{m+n}} \cdot \frac{x^{m}}{m !} \cdot \frac{y^{n}}{n !}, \\
Z_{2}(x, y)=y^{1-\delta^{\prime}}\left\{1+\frac{x}{\delta\left(\gamma+1-\delta^{\prime}\right)}+\frac{y}{(2-\delta)\left(\gamma+1-\delta^{\prime}\right)}+\frac{x y}{\delta\left(2-\delta^{\prime}\right)\left(\gamma+1-\delta^{\prime}\right)\left(\gamma+2-\delta^{\prime}\right)}+\ldots\right\} \\
Z_{3}(x, y)=x^{1-\delta}\left\{1+\frac{x y}{(2-\delta)(\gamma+1-\delta)}+\frac{y}{\delta(\gamma+1-\delta)}+\frac{x y}{\delta^{\prime}(2-\delta)(\gamma+1-\delta)(\gamma+2-\delta)}+\ldots\right\} \\
Z_{4}(x, y)=y^{1-\gamma}\left\{1+\frac{x}{\delta}+\frac{x}{(2-\gamma)\left(\delta^{\prime}+1-\gamma\right)}+\frac{x}{2 \delta(2-\gamma)\left(\delta^{\prime}+1-\gamma\right)}+\frac{x^{2}}{2^{2} \delta(\delta+1)}+\ldots\right\} \\
Z_{5}(x, y)=x^{1-\delta} y^{1-\delta^{\prime}}\left\{1+\frac{x}{(2-\delta)\left(\gamma+2-\delta-\delta^{\prime}\right)}+\frac{x}{\left(2-\delta^{\prime}\right)\left(\gamma+2-\delta-\delta^{\prime}\right)}+\right. \\
\left.+\frac{x y}{(2-\delta)\left(2-\delta^{\prime}\right)\left(\gamma+2-\delta-\delta^{\prime}\right)\left(\gamma+3-\delta-\delta^{\prime}\right)}+\ldots\right\} \\
Z_{6}(x, y)=x^{1-\delta} y^{1-\gamma}\left\{1+\frac{x}{(2-\delta)^{2}}+\frac{y}{(2-\delta)\left(\delta^{\prime}+1-\gamma\right)}+\frac{x y}{(2-\delta)^{2}(3-\delta)(2-\gamma)\left(1+\gamma-\delta^{\prime}\right)}+\ldots\right\} \\
Z_{7}(x, y)=x^{1-\gamma}\left\{1+\frac{x y}{(2-\gamma)(\delta+1-\gamma)}+\frac{y}{\delta^{\prime}}+\frac{x}{2 \delta^{\prime}(2-\gamma)(1+\delta-\gamma)}+\ldots\right\} \\
Z_{8}(x, y)=x^{1-\gamma} y^{1-\delta^{\prime}}\left\{1+\frac{x}{(2-\gamma)\left(2-\delta^{\prime}\right)(\delta+1-\gamma)}+\frac{y}{\left(2-\delta^{\prime}\right)^{2}}+\right. \\
\left.+\frac{x y}{\left(2-\delta^{\prime}\right)^{2}(2-\gamma)(\delta+1-\gamma)\left(3-\delta^{\prime}\right)}+\ldots\right\}, \\
Z_{9}(x, y)=x^{1-\gamma} y^{1-\gamma}\left\{1+\frac{x}{(2-\gamma)^{2}(1+\delta-\gamma)}+\frac{x y}{(2-\gamma)^{2}(1+\delta-\gamma)}+\ldots\right\} . \\
y
\end{gathered}
$$

Proof. The system is consistent in construction system (2.14). We will construct solutions using the Frobenius-Latvian method, based on the results of clause 2.1. The system of defining equations for the singularity $(0,0)$ :

$$
\begin{gathered}
f_{00}^{(1)}(\rho, \sigma)=\rho(\rho-1)(\rho-2)+\rho(\rho-1) \sigma+(\gamma+\delta+1) \rho(\rho-1)+\delta \rho \sigma+\gamma \delta=0, \\
f_{00}^{(1)}(\rho, \sigma)=\sigma(\sigma-1)(\sigma-2)+\rho \sigma(\sigma-1)+\left(\gamma+\delta^{\prime}+1\right) \sigma(\sigma-1)+\delta^{\prime} \rho \sigma+\gamma \delta^{\prime}=0
\end{gathered}
$$

has nine pairs of roots:

$$
\begin{gathered}
\text { 1. }\left(\rho_{1}=0, \sigma_{1}=0\right) ; 2 \cdot\left(\rho_{1}=0, \sigma_{2}=1-\delta^{\prime}\right) ; 3 \cdot\left(\rho_{2}=1-\delta, \sigma_{1}=0\right) ; \\
\text { 4. }\left(\rho_{1}=0, \sigma_{3}=1-\gamma\right) ; 5 .\left(\rho_{2}=1-\delta, \sigma_{2}=1-\delta^{\prime}\right) ; 6 .\left(\rho_{2}=1-\delta, \sigma_{3}=1-\gamma\right) ; \\
\text { 7. }\left(\rho_{3}=1-\gamma, \sigma_{1}=0\right) ; 8 .\left(\rho_{3}=1-\gamma, \sigma_{2}=1-\delta^{\prime}\right) ; 9 .\left(\rho_{3}=1-\gamma, \sigma_{3}=1-\gamma\right) .
\end{gathered}
$$


Using the system of recurrent sequences (2.8), we determine the unknown coefficients of the series (2.4) sequentially substituting the values of the roots pairs $\left(\rho_{t}, \sigma_{t}\right)(t=\overline{1,9})$ of system defining equations (2.17).

In this way, we obtain nine linearly independent particular solutions (2.16). The theorem is proved. Now we proceed to construct a particular solution of an inhomogeneous system

$$
\begin{aligned}
& x^{2} Z_{x x x}+x y Z_{x x y}+(\gamma+\delta+1) x Z_{x x}+\delta y Z_{x y}+\gamma \delta Z_{x}-Z=g^{(7)}(x, y), \\
& y^{2} Z_{y y y}+x y Z_{x y y}+\left(\gamma+\delta^{\prime}+1\right) y Z_{y y}+\delta^{\prime} x Z_{x y}+\gamma \delta^{\prime} Z_{y}-Z=q^{(7)}(x, y),
\end{aligned}
$$

where the right side has the type

$$
\begin{aligned}
& g^{(7)}(x, y)=\gamma^{2} \delta \delta^{\prime}+\frac{1}{\gamma \delta} x+\frac{1}{\gamma \delta^{\prime}} y \\
& q^{(7)}(x, y)=\gamma^{2} \delta \delta^{\prime}+\frac{1}{\gamma \delta} x+\frac{1}{\gamma \delta^{\prime}} y
\end{aligned}
$$

Theorem 2.6. The general solution of the inhomogeneous system (2.18) with the right part (2.19) is represented as the sum $(2.10)$ of the total solution $\bar{Z}(x, y)$ the corresponding homogeneous system (2.15) and a particular solution $Z_{0}(x, y)$ heterogeneous system $(2.18)$.

Indeed, by virtue of Theorem 2.3, the general solution of the corresponding homogeneous system (2.15) is represented as the sum of nine linearly independent particular solutions $Z_{j}(x, y),(j=\overline{1,9})$ (2.16):

$$
\bar{Z}(x, y)=\sum_{m, n=0}^{\infty} C_{j} Z_{j}(x, y),(j=\overline{1,9}) .
$$

It remains to build a particular solution $Z_{0}(x, y)$ of heterogeneous system (2.18) with the right part (2.19) using the method of uncertain coefficients described in clause 2.2 based on the right part of task $g^{(7)}(x, y)$ and $q^{(7)}(x, y)$ in view of

$$
Z_{0}(x, y)=C_{0,0}+C_{1,0} x+C_{0,1} y
$$

Substituting (2.20) into (2.15) we determine the unknown coefficients: $C_{0,0}=-\left(\gamma^{2} \delta \delta^{\prime}+1\right), C_{1,0}=-\frac{1}{\gamma \delta}$, $C_{0,1}=-\frac{1}{\gamma \delta^{\prime}}$ obtain a particular solution of the inhomogeneous system (2.18) with the right side $g^{(7)}(x, y)$ and $q^{(7)}(x, y)$ in view of

$$
Z_{0}(x, y)=-\left(\gamma^{2} \delta \delta^{\prime}+1\right)-\frac{x}{\gamma \delta}-\frac{y}{\gamma \delta^{\prime}} .
$$

Therefore, the general solution of inhomogeneous system (2.18) with the right-hand side (2.19) is represented as

$$
Z(x, y)=\bar{Z}(x, y)+Z_{0}(x, y)=\sum_{j=1}^{9} C_{j} Z_{j}(x, y)-\left(\gamma^{2} \delta \delta^{\prime}+1\right)-\frac{x}{\gamma \delta}-\frac{y}{\gamma \delta^{\prime}},
$$

where $Z_{j}(x, y),(j=\overline{1,9})$ particular solutions corresponding to homogeneous system (2.16).

It is easy to verify that the sum of two equations (2.18) also satisfy the particular solution of the inhomogeneous system (2.21).

Theorem 2.7. A particular solution of the inhomogeneous system (2.21) is also a solution of a third-order partial differential equation

$$
x^{2} Z_{x x x}+x y Z_{x x y}+y^{2} Z_{y y y}+x y Z_{x y y}+(\gamma+\delta+1) x Z_{x x}+\left(\gamma+\delta^{\prime}+1\right) y Z_{y y}+
$$




$$
+\left(\delta y+\delta^{\prime} x\right) Z_{x y}+\gamma \delta Z_{x}+\gamma \delta^{\prime} Z_{y}-2 Z=2\left(\gamma^{2} \delta \delta^{\prime}+\frac{x}{\gamma \delta}+\frac{y}{\gamma \delta^{\prime}}\right)
$$

obtained by adding the two equations of the inhomogeneous system (2.18).

Theorem 2.8. The general solution of the inhomogeneous system (2.22) is a solution of a third-order partial differential equation (2.23) obtained by adding two equations of the inhomogeneous system (2.18).

Conclusions: Thus, in this paper we have been studied the possibility of constructing solutions uncharted inhomogeneous system of differential equations in partial derivatives, consisting of two thirdorder equations.

1. To solve the corresponding homogeneous system (2.3) was applied the Frobenius-Latyshev method. Theorems 2.1 and 2.2 on the number of linearly independent solutions of the homogeneous system (2.3) have been proved. The main stages of building solutions by the Frobenius-Latyshev method are given. It was found that when the roots of the defining systems (2.6) and (2.7) with respect to characteristics $(0,0)$ and $(\infty, \infty)$ simple, the homogeneous system has nine linearly independent particular solutions of species (2.4) or (2.5) near the singularities of $(0,0)$ and $(\infty, \infty)$.

2. A theorem on the construction a general solution of the inhomogeneous system (2.1) with coefficients in type (2.2) is formulated. To this end, for such systems, for the first time the method of uncertain coefficients is used. Yu.I. Sikorskiy extended method of Frobenius-Latysheva to linear ordinary inhomogeneous differential equations [12, 13]. It has been shown that for solving various problems of thermoelasticity, the method of undetermined coefficients has an advantage over the method of arbitrary constant [14]. For example, when solving the inhomogeneous Bessel equation, particular solution is a linear combination of Lommel functions [15]. It should be noted that in this monograph thoroughly studied the possibility of constructing the solutions known classical ordinary differential equations with the right-hand side, the decisions of which are special functions and orthogonal polynomials in one variable. In the case of the studied systems, the research has not reached such a level.

3. A specific example is considered, where a homogeneous system is constructed by the method of J. Kampe de Feriet [2; 155-169]. Nine linearly independent solutions (2.16) obtained by the FrobeniusLatysheva. To build a general solution of system (2.18) with the right-hand side (2.19), the undetermined coefficients method is applied.

4. It is also shown that application of uncertain coefficients method allows to obtain solutions of one inhomogeneous partial differential equation of the third order (2.23) associated with the studied specific system (2.18).

5. The first particular solution of homogeneous system (2.15) relates to degenerate generalized hypergeometric series of two variables Clausen type

$$
\begin{aligned}
F\left(\cdot ; \delta, \delta^{\prime}, \gamma ; x, y\right)=1+ & \frac{1}{\delta \gamma} x+\frac{1}{\delta^{\prime} \gamma} y+\frac{x y}{\delta \delta^{\prime} \gamma(\gamma+1)}+\frac{1}{\delta(\delta+1) \gamma(\gamma+1)} \cdot \frac{x^{2}}{2 !}+ \\
& +\frac{1}{\delta^{\prime}\left(\delta^{\prime}+1\right) \gamma(\gamma+1)} \cdot \frac{y^{2}}{2 !}+\ldots
\end{aligned}
$$

The properties of this series remain understood. Consider the differential properties of the series (2.24).

Theorem 2.9. First $m$ and $n$ the of the series (2.24) are represented as:

$$
\begin{aligned}
& 1 . \frac{\partial}{\partial x} F\left(\cdot ; \delta, \delta^{\prime}, \gamma ; x, y\right)=\frac{1}{\delta \gamma} F\left(\cdot ; \delta+1, \delta^{\prime}, \gamma+1 ; x, y\right), \\
& 2 \cdot \frac{\partial}{\partial y} F\left(\cdot ; \delta, \delta^{\prime}, \gamma ; x, y\right)=\frac{1}{\delta^{\prime} \gamma} F\left(\cdot ; \delta, \delta^{\prime}+1, \gamma+1 ; x, y\right) \text {, } \\
& 3 . \frac{\partial^{2} F\left(\cdot ; \delta, \delta^{\prime}, \gamma ; x, y\right)}{\partial x^{2}}=\frac{F\left(\cdot ; \delta+2, \delta^{\prime}, \gamma+2 ; x, y\right)}{\delta(\delta+1) \gamma(\gamma+1))},
\end{aligned}
$$




$$
\begin{gathered}
4 . \frac{\partial^{2} F\left(\cdot ; \delta, \delta^{\prime}, \gamma ; x, y\right)}{\partial y^{2}}=\frac{F\left(\cdot ; \delta, \delta^{\prime}+2, \gamma+2 ; x, y\right)}{\left.\delta^{\prime}\left(\delta^{\prime}+1\right) \gamma(\gamma+1)\right)}, \\
5 \cdot \frac{\partial^{2} F\left(\cdot ; \delta, \delta^{\prime}, \gamma ; x, y\right)}{\partial x \partial y}=\frac{F\left(\cdot ; \delta+1, \delta^{\prime}+1, \gamma+2 ; x, y\right)}{\delta \delta^{\prime} \gamma(\gamma+1)}, \\
6 . \frac{\partial^{m_{1}} F\left(\cdot ; \delta, \delta^{\prime}, \gamma ; x, y\right)}{\partial x^{m_{1}}}=\frac{F\left(\cdot ; \delta+m_{1}, \delta^{\prime}, \gamma+m_{1} ; x, y\right)}{\delta(\delta+1) \ldots\left(\delta+m_{1}\right) \gamma(\gamma+1) \ldots(\gamma+2)}, \\
7 . \frac{\partial^{m_{2}} F\left(\cdot ; \delta, \delta^{\prime}+1, \gamma+m_{2} ; x, y\right)}{\partial y^{m_{2}}}=\frac{F\left(\cdot ; \delta, \delta^{\prime}+m_{2}, \gamma+m_{2} ; x, y\right)}{\delta^{\prime}\left(\delta^{\prime}+1\right) \ldots\left(\delta^{\prime}+m_{2}\right) \gamma(\gamma+1) \ldots\left(\gamma+m_{2}\right)}, \\
8 \cdot \frac{\partial^{m_{1}+m_{2}} F\left(\cdot ; \delta, \delta^{\prime}, \gamma ; x, y\right)}{\partial x^{m_{1}} \partial y^{m_{2}}}= \\
\frac{F\left(\cdot ; \delta+m_{1}, \delta^{\prime}+m_{2}, \gamma+m_{1}+m_{2} ; x, y\right)}{\delta(\delta+1) \ldots\left(\delta+m_{1}\right) \delta^{\prime}\left(\delta^{\prime}+1\right) \ldots\left(\delta^{\prime}+m_{2}\right) \gamma(\gamma+1) \ldots\left(\gamma+m_{1}+m_{2}\right)} .
\end{gathered}
$$

Confine ourselves with building a single solution corresponding to the indicator $\left(\rho_{1}=0, \sigma_{1}=0\right)$. Similarly, the differential properties of the remaining series in (2.16) can be derived. The output of these differential properties further facilitates the proof of theorem addition and multiplication, while others recurrence relations associated with degenerate generalized hypergeometric series.

\section{References}

1 Wilczynski E.J. Projective differential geometry of Curves and Ruled surfaces / E.J. Wilczynski. - Leipzig: Leubner, 1966. - 120 p.

2 Appell P. Fonctions hypergeometriques et hypesperiques / P. Appell, M.J. Kampe de Feriet. Paris: Gauthier Villars, 1926. - 434 p.

3 Slater L.J. Hypergeometric functions / L.J. Slater, D. Lit. - Ph.D. Generalized: Cambridge At the university Press, 1966. - 292 p.

4 Beytmen G. Higher Transcendental Functions / G. Beytmen, A. Erdeyli.- M.: Science, 1965. $294 \mathrm{p}$.

5 Тасмамбетов Ж.Н. Об одной системе дифференциальных уравнений в частных производных второго порядка / Ж.Н. Тасмамбетов // Украин. мат. журн. - 1992. - Т. 44, № 1. C. $427-430$.

6 Тасмамбетов Ж.Н. Построение нормальных и нормально-регулярных решений специальных систем дифференциальных уравнений в частных производных второго порядка / Ж.Н. Тасмамбетов. - Актобе: ИП Жандилдаева С.Т., 2015. - 464 с.

7 Тасмамбетов Ж.Н. Многочлены Лежандра двух переменных как решения приведенной системы в частных производных / Ж.Н. Тасмамбетов // Проблемы оптимизации сложных систем: материалы X Междунар.-азиат. шк.-сем. (25 июля - 5 августа 2014 г.). - Ч. 2. С. 655-661. - Иссык-Куль, 2014.

8 Талипова М.Ж. Построение нормальных решений неоднородных систем дифференциальных уравнений в частных производных второго порядка: автореф. ... канд. дис. / М.Ж. Талипова. - Алматы, 2007. - 20 с.

9 Тасмамбетов Ж.Н. Нахождение нормально-регулярных решений неоднородной системы дифференциальных уравнений в частных производных второго порядка / Ж.Н. Тасмамбетов, М.Ж. Талипова // Изв. МОН НАН РК. Сер. физ.-мат. - 2003. - № 3. - С. 47-55.

10 Ince E.L. Ordinary Differential Equations / E.L. Ince. - London: New York \& Bombay; Longmans, GreenCo, 1926. - 14 p. 
11 Kampe de Feriet M.J. Fonctions de la Physique Mathematique Fascicule X / M.J. Kampe de Feriet, R.Kambell, Pet'o G., Fohell' T. - Sous la direction de. Centre national de la Recherchй scientifique, 1957. - $102 \mathrm{p}$.

12 Сикорский Ю.И. О неоднородных линейных дифференциальных уравнениях в регулярном случае / Ю.И. Сикорский, Н.И. Терещенко // Математическая физика: Респ. межведом. сб. - Киев, 1972. - С. 133-137.

13 Сикорский Ю.И. Об условиях существования замкнутых решений линейного неоднородного дифференциального уравнения с полиномиальными коэффициентами / Ю.И. Сикорский, Н.И. Терещенко // Украин. мат. журн. - 1973. - Т. 25, № 4. - С. 558-563.

14 Sidlyar M.M. Thermostressed state of a round Cylinder in case of interaction of the temperature field and deformations / M.M. Sidlyar, Yu.I. Sikorsky, N.I. Tereshenko. - Kiev: Reports of the Ukrainian Academy of Sciences.

15 Babister A.W. Trancendental function satisfying nonhomogeneous linear differential equations / A.W. Babister. - New York-London, 1967. - 414 p.

\title{
Ж.Н. Тасмамбетов, Ж.К. Убаева \\ Дербес туындылы үшінші ретті дифференциалдық біртектіемес жүйелер шешімі
}

\begin{abstract}
Үшінші ретті дербес туындылы біртектіемес дифференциалдық теңдеулер жүйесінің шешімдерін құру мүмкіндіктері зерттелген. Фробениус-Латышева әдісімен сәйкес біртекті жүйенің жалпы және дербес шешімдерін құру жан-жақты қарастырылған. Сызықты-тәуелсіз дербес шешімдер саны анықталған. Мұндай жүйелерге анықталмаған коэффициенттер әдісін қолдану ерекешеліктері айқындалған және біртекті емес жүйенің жалпы шешімі туралы теорема дәлелденген. Нақты мысалда, осындай жолмен құрылған біртекті емес жүйенің дербес шешімі, қарастырылған мысалдағы теңдеулер жүйесінің екі теңдеуін қосындылаудан алынған үшінші ретті, біртекті емес бір теңдеудің де шешімі болатындығы көрсетілген. Сәйкес біртекті жүйенің дербес шешімдерінің бірі екі айнымалының Клаузен текті туындалған жалпыланған гипергеометриялық қатар түріне жатады. Мұндай жалпыланған гипергеометриялық қатарлардың қасиеттері әзірше аз зерттелген.
\end{abstract}

Kiлm сөздер: біртекті емес жүйе, регулярлы шешім, ерекше нүктелер, белгісіз коэффициенттер әдісі, жүйе, теңдеулер, теорема.

\author{
Ж.Н. Тасмамбетов, Ж.К. Убаева
}

\section{Решение неоднородных систем дифференциальных уравнений в частных производных третьего порядка}

\begin{abstract}
Изучены возможности построения решений неоднородной системы дифференциальных уравнений в частных производных третьего порядка. Методом Фробениуса-Латышевой всесторонне исследовано построение общего и частных решений соответствующей однородной системы. Установлены виды решения вблизи особых кривых. Определено количество линейно-независимых частных решений. Доказана теорема о представлении общего решения неоднородной системы и раскрыты особенности применения метода неопределенных коэффициентов для таких систем. На конкретном примере показано, что построенные таким образом частные решения неоднородной системы являются решениями и одного неоднородного уравнения третьего порядка, полученного путем сложения двух уравнений рассмотренного примера. Одно из частных решений соответствующей однородной системы относится к виду вырожденного обобщенного гипергеометрического ряда типа Клаузена двух переменных. Свойства таких обобщенных гипергеометрических рядов остаются мало изученными.
\end{abstract}

Ключевые слова: неоднородная система, регулярное решение, особенность, метод неопределенных коэффициентов, система, уравнения, теорема. 


\section{References}

1 Wilczynski, E.J. (1966). Projective differential geometry of Curves and Ruled surfaces. Leipzig: Leubner.

2 Appell, P., \& Kampe de Feriet, M.J. (1926). Fonctions hypergeometriques et hypesperiques. Paris: Gauthier Villars.

3 Slater, L.J., \& Lit, D. (1966). Generalized Hypergeometric functions. Ph.D. Generalized: Cambridge at the university Press.

4 Beytmen, G., \& Erdeyli, A. (1965). Higher Transcendental Functions. Moscow: Nauka.

5 Tasmambetov, Zh.N. (1992). Ob odnoi sisteme differentsialnykh uravnenii v chastnykh proizvodnykh vtoroho poriadka [On a system of partial differential equations of second order]. Ukrainskii matematicheskii zhurnal - Ukrainian Mathematical Journal, 44, 3, 427-430 [in Russian].

6 Tasmambetov, Zh.N. (2015). Postroenie normalnykh i normalno-rehuliarnykh reshenii spetsialnykh sistem differentsialnykh uravnenii $v$ chastnykh proizvodnykh vtoroho poriadka /Construction of normal and normally-regular solutions of special systems of partial equations of second order]. Aktobe: IP Zhanadildaeva S.T. [in Russian].

7 Tasmambetov, Zh.N. (2014). Mnohochleny Lenzhandra dvukh peremennykh kak resheniia privedennoi sistemy $\mathrm{v}$ chastnykh proizvodnykh [The Legendre polynomials of two variables as solutions of the reduced system in partial derivatives]. Problems of optimization of complex systems: Acta Internationalis decima-Asian schola-seminario (25 Iulii-5 August 2014 hoda) - Proceedings of the tenth International-Asian school-seminar (Part II, p. 655-661) [in Russian].

8 Talipova, M.Zh. (2007). Postroenie normalnykh reshenii neodnorodnykh sistem differentsialnykh uravnenii v chastnykh proizvodnykh vtoroho poriadka [Constructing normal solutions for inhomogeneous systems of second-order partial differential equations]. Extended abstract of Doctor's thesis. Almaty [in Russian].

9 Tasmambetov, Zh.N., \& Talipova, M.Zh. (2003). Nakhozhdenie normalno-rehuliarnykh reshenii neodnorodnoi sistemy differentsialnykh uravnenii $\mathrm{v}$ chastnykh proizvodnykh vtoroho poriadka [Finding normally-regular solutions of an inhomogeneous system of second-order partial differential equations]. Izvestiia MON NAN RK. Seriia fiziko-matematicheskaia - News of MON NAS RK. Physical-mathematical series, 3, 47-55 [in Russian].

10 Ince, E.L. (1926). Ordinary Differential Equations. London: New York \& Bombay; Longmans, GreenCo.

11 Kampe de Feriet, M.J., \& Kambell, R., \& Pet'o, G., \& Fohell', T. (1957). Fonctions de la Physique Mathematique. Fascicule IX. Centre national de la Recherchй scientifique.

12 Sikorsky, Yu.I., \& Tereshchenko, N.I. (1972). O neodnorodnykh lineinykh differentsialnykh uravneniiakh $\mathrm{v}$ rehuliarnom sluchae [On inhomogeneous linear differential equations in the regular case]. Mathematicheskaia fizika: Respublikanskii mezhvedomstvennyi sbornik - Republican interdepartmental collection, 133-137 [in Russian].

13 Sikorsky, Yu.I., \& Tereshchenko, N.I. (1973). Ob usloviiakh sushchestvovaniia zamknutykh reshenii lineinoho neodnorodnoho differentsialnoho uravneniia s polinomialnymi koeffitsientami [On the conditions for the existence of closed decision by the linear inhomogeneous differential equation with polynomial coefficients]. Ukrainskii matematicheskii zhurnal - Ukrainian Mathematical Journal, 25, 4, 558-563 [in Russian].

14 Sidlyar, M.M., \& Sikorsky, Yu.I., \& Tereshenko, N.I. (1971). Thermostressed state of a round Cylinder in case of interaction of the temperature field and deformations. Kiev: Reports of the Ukrainian Academy of Sciences.

15 Babister, A.W. (1967). Trancendental function satisfying nonhomogeneous linear differential equations. New York-London. 